\title{
Quality control evaluation and acetylcholinesterase inhibitory activity of Galanthus woronowii Losinsk.
}

\author{
Ahmet Emir, Nehir Ünver Somer, Gülen İrem Kaya, Buket Sarıkaya, Mustafa Ali Önür
}

\begin{abstract}
Aerial and underground parts of Galanthus woronowii Losinsk., a wild growing species in north-eastern Anatolia, were collected during flowering period. Quality control and acetylcholinesterase inhibitory activity determinations were carried out on Bulbus and Herba Galanthi prepared from plants collected from two different localities. In the context of quality control studies, contents of humidity, total ash, sulphated ash, acid-insoluble ash and total alkaloids of the drug specimens were determined and found to range between 8.463-9.343\%, 6.950-14.947\%, 9.743-17.930\%, 1.102-3.565\% and 0.247-0.499\%, respectively. Additionally, acetylcholinesterase inhibitory activity of the alkaloidal extracts prepared from the drug specimens were determined by using Thin Layer Chromatography (TLC) combined with a bioautographic assay based on in vitro Ellman method. All of the alkaloidal extracts displayed acetylcholinesterase inhibitory activity.
\end{abstract}

KEY WORDS: Galanthus woronowii, Amaryllidaceae, Quality control determination, Acetylcholinesterase inhibitory activity

\section{INTRODUCTION}

Galanthus woronowii Losinsk., is one of the fourteen species (fifteen taxa) of Galanthus L. growing naturally in Turkey $(1,2)$. It is distributed in Caucasus, Transcaucasus, southern Russia, Georgia and northeastern Turkey $(3,4)$. This species is a low-to mid altitude species, growing at altitudes from 20 to $1500 \mathrm{~m}$ however more

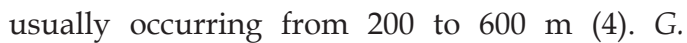
woronowii with broad green leaves is an attractive plant for gardening (4). Among the Galanthus species growing in Turkey, together with the bulbs of G. elwesii Hook., bulbs of G. woronowii are exported $(5,6)$.

Previous investigations on G. woronowii resulted in the isolation of several Amaryllidaceae alkaloids (7-10). This group of alkaloids are known to exhibit interesting biological properties such as antiviral (11), antitumor (12), antimalarial (13) and acetylcholinesterase inhibitory activities (14). Among these alkaloids galanthamine is an acetylcholinesterase inhibitor and therefore, it is used in the treatment of Alzheimer's disease (15).

Comprising a part of our ongoing studies on Turkish Galanthus species, the present study was undertaken to determine the quality standarts of drugs prepared from the aerial parts and bulbs of G. woronowii collected during flowering period. The gravimetric determinations of humidity, total ash, sulphated ash, acid-insoluble ash and also titrimetric determinations of the total alkaloidal content were carried out according to European Pharmacopeia (16). Moreover, with the aim of determining the acetylcholinesterase inhibitor potential of this plant, alkaloidal extracts prepared from the aerial parts and bulbs of G. woronowii, were screened for their acetylcholinesterase inhibitory activity by using Thin Layer Chromatography (TLC) combined with a bioautographic assay based on in vitro Ellman method (17).

\section{MATERIALS AND METHODS}

\section{Plant Material}

Galanthus woronowii Losinsk. samples were collected during flowering period, from Çaykara, Trabzon in March 2006 and from Derepazar1, Rize in March 2009. The plants were identified by one of us (M. A. Önür). Voucher samples (No's 1358 and 1417) are deposited in the Herbarium of
AFFILIATIONS

Ege Üniversitesi, Eczacılık Fakültesi/Farmakognozi AD, İzmir, Türkiye

CORRESPONDENCE

Nehir Ünver Somer

E-mail:

nehir.somer@ege.edu.tr

Received:

21.01.2011

Revision:

02.03.2011

Accepted:

02.03.2011 
TABLE 1. Quality control determination results of G. woronowii

\begin{tabular}{lcccc}
\hline Specimen\# & Humidity (\%)* & Total Ash (\%)* & Sulphated Ash (\%)* & Hydrochloric Acid- Insoluble Ash (\%)* $^{*}$ Total Alkaloids (\%)* $^{*}$ \\
\hline 1 & $9.263 \pm 0.012$ & $8.857 \pm 0.050$ & $13.567 \pm 0.101$ & $1.102 \pm 0.032$ \\
2 & $9.343 \pm 0.021$ & $14.460 \pm 0.046$ & $17.930 \pm 0.118$ & $3.565 \pm 0.112$ \\
3 & $8.472 \pm 0.010$ & $6.950 \pm 0.078$ & $9.743 \pm 0.015$ & 0.005 \\
4 & $8.463 \pm 0.025$ & $14.947 \pm 0.031$ & $11.190 \pm 0.053$ & $0.499 \pm 0.006$ \\
\hline
\end{tabular}

\#1: Bulbus/Derepazarı,Rize; 2: Herba/Derepazarı,Rize; 3: Bulbus/Çaykara,Trabzon; 4: Herba/Çaykara,Trabzon

${ }^{*} \mathrm{n}=3$, Mean Results \pm Standard Deviations

the Department of Pharmacognosy, Faculty of Pharmacy, Ege University.

\section{Chemicals}

Acetylthiocholine iodide (ATCI), acetylcholinesterase enzyme (AchE) type VI-S from electric eel, 5,5-dithiobis[2-nitrobenzoic acid] (DTNB) were purchased from Sigma. Tris- $\mathrm{HCl}$ was obtained from Merck. Galanthamine was isolated from various Amaryllidaceae plants in our laboratory and identified by spectroscopic analysis (UV, IR, MS, NMR) (18). The other chemicals were of analytical purity.

\section{Quality Control Determinations}

European Pharmacopeia was referred to for the gravimetric assays of humidity, total ash, sulphated ash acid-insoluble ash. The total alkaloidal content of each drug specimen was

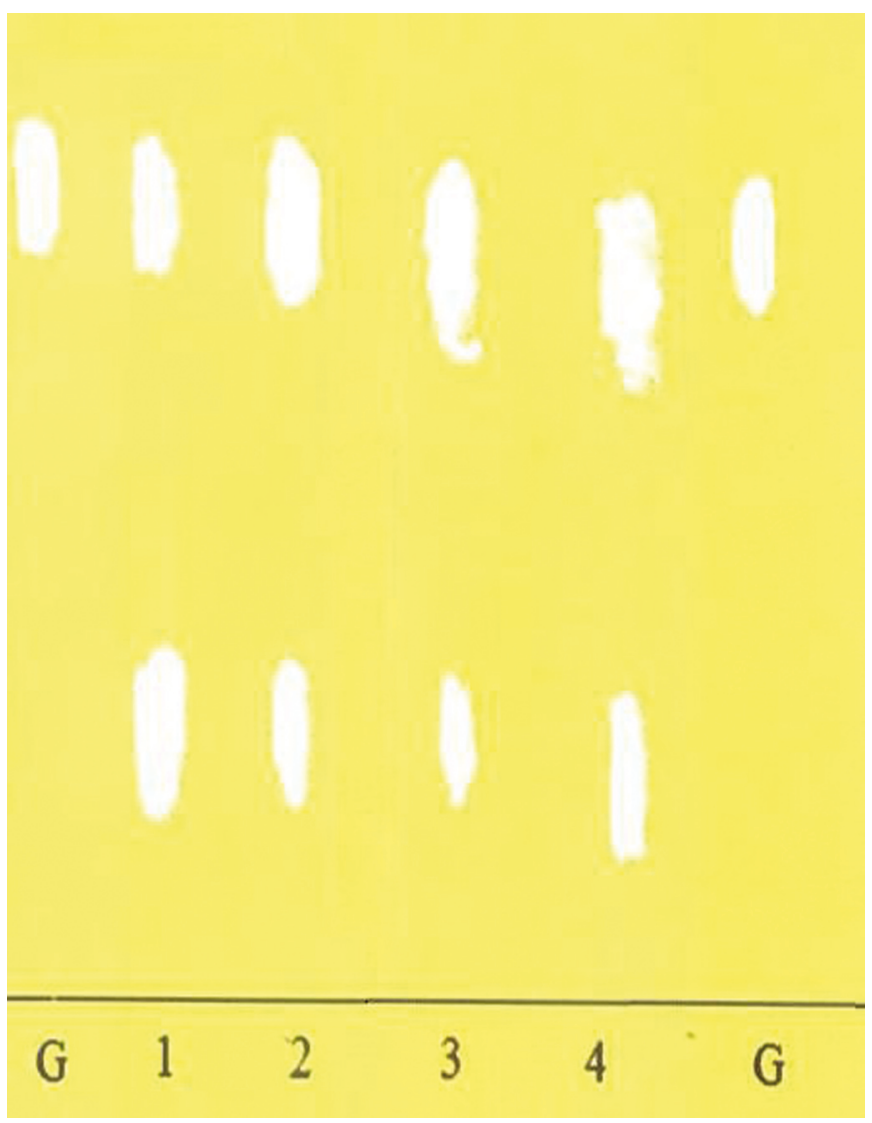

FIGURE 1: AChE inhibitory activity of alkaloidal extracts of G. woronowii. G: Galanthamine, 1: Bulbus/Derepazarı,Rize; 2: Herba/Derepazarı,Rize; 3: Bulbus/ Çaykara,Trabzon; 4: Herba/Çaykara,Trabzon. White spots indicate inhibition. evaluated by using a titrimetric method cited in European Pharmacopeia for different alkaloid-containing drugs (16) and alkaloid extraction was carried out as described, previously (19).

\section{Acetylcholinesterase Inhibitory Activity Determination}

The method used for the determination of acetylcholinesterase inhibitory activity was modified from a previous study (17). 20 microliters of each plant extract $(10 \mathrm{mg} / \mathrm{ml})$ and 10 microliters of galanthamine $(1.5 \mathrm{mg} / \mathrm{ml})$ dissolved in chloroform-methanol $(8: 2)$, were spotted on a TLC plate (Silica gel $\mathrm{F}_{254}, 0.2 \mathrm{~mm}$, Aluminium sheet, Merck). Chloroformmethanol (8:2) mixture was used as the mobile phase for the development of the TLC plate. The plate was allowed to dry at room temperature, then it was sprayed with $1 \mathrm{mM}$ ATCI and $1 \mathrm{mM}$ DTNB in Tris-HCl, pH:8. After 3-5 minutes drying, the plate was sprayed with 3 Unit/ml AChE in Tris- $\mathrm{HCl}$, $\mathrm{pH}: 8$. 20 minutes later, a yellow background appeared; occurrence of white spots marked positive reaction.

\section{RESULTS AND DISCUSSION}

The results obtained from the humidity, total ash, sulphated ash, acid-insoluble ash and total alkaloid determination assays are reported in Table 1. During the course of our ongoing studies on Turkish Galanthus species, previously Herba and Bulbus Galanthi drugs prepared from G. elwesii Hook., G. gracilis Ćelak., G. trojanus A.P. Davis \& N. Özhatay and G. plicatus Bieb. subsp. byzantinus (Baker) D. A. Webb were investigated for their contents of humidity, total ash, sulphated ash and total alkaloids (19-22). Previous data and the results of the present study, may be utilized for the determination of the standard values for the elaboration of prospective monographs on Herba and Bulbus Galanthi.

The total alkaloidal content is an important criterion for the evaluation of the quality of Herba and Bulbus Galanthi. In our study, the total alkaloids ranged between 0.247-0.499\%. Aerial parts of G. woronowii collected from Derepazarı, Rize were found to contain the maximal amount of total alkaloids. The minimal amount of total alkaloids was detected in the aerial parts of G. woronowii collected from Çaykara, Trabzon (Table 1). Previously, the contents of individiual alkaloids and the quantity of the total bases obtained during isolation studies have been reported for this plant $(10,23,24)$. However, to the best of our knowledge, this is the first report on the quantification of the total alkaloids in G. woronowii.

In addition to the quality control determinations, acetylcholinesterase inhibitor potentials of the alkaloidal extracts were screened by TLC in combination with bioactivity staining based on Ellman's method. The active extracts were 


\section{Galanthus woronowii Losinsk.'in kalite kontrol açısından değerlendirilmesi ve asetilkolinesteraz inhibitör aktivitesi}

ÖZET: Kuzeydoğu Anadolu'da doğal olarak yetişen Galanthus woronowii Losinsk.'in toprak üstü ve toprak altı kısımları bitki çiçekli dönemde iken toplanmıştır. İki farklı lokaliteden toplanan bitkilerden hazırlanan Bulbus ve Herba Galanthi drogları üzerinde kalite kontrol ve asetilkolinesteraz inhibitör aktivite tayinleri gerçekleştirilmiştir. Kalite kontrol çalışmaları kapsamında drog örneklerinin nem, total kül, sülfat külü, hidroklorik asitte çözünmeyen kül ve total alkaloit içerikleri saptanmış ve bunların sırasıyla \% 8.463-9.343, \% 6.950-14.947, \% 9.743-17.930, \% 1.102-3.565 ve \% 0.247-0.499 arasında değiştiği bulunmuştur. İlaveten, drog örneklerinden hazırlanan alkaloit ekstrelerinin asetilkolinesteraz inhibitör aktiviteleri in vitro Ellman yöntemine dayalı biyootografik bir deney ile kombine edilen İnce Tabaka Kromatografisinden (ITK) yararlanılarak tespit edilmiştir. Bütün alkaloit ekstreleri asetilkolinesteraz inhibitör aktivite göstermiştir.

ANAHTAR KELIMELER: Galanthus woronowii, Amaryllidaceae, Kalite kontrol tayini, Asetilkolinesteraz inhibitör aktivite

detected by the formation of white spots after spraying the substrate, dye and enzyme which gave a yellow background (17). All of the alkaloidal extracts contained galanthamine and also other alkaloids with AchE inhibitory activity (Figure 1). It is already known that AchE inhibitory activity is related mainly with galanthamine- and lycorine-type Amaryllidaceae alkaloids $(14,25,26)$. Our ongoing phytochemical studies on this species, revealed that $G$. woronowii contained galanthamine, lycorine and other alkaloids belonging to the galanthamine- or lycorine-type of Amaryllidaceae alkaloids $(18,27,28)$ which have been previously shown to possess AchE inhibitory activity $(14,25,27)$.

\section{ACKNOWLEDGEMENTS}

This study was financially supported by Ege University Research Fund (No: 09/ECZ/08) and partially supported by TUBITAK (No:104T272) and EBILTEM (No: 2007/BIL/007).

\section{REFERENCES}

1. Davis AP. Galanthus L. In: Flora of Turkey and the East Aegean Islands. Editors: Adil Güner, Neriman Özhatay, Tuna Ekim, Kemal Hüsnü Can Başer, Edinburgh University Press, Edinburgh. 2000, vol. 11, pp.265-270.

2. Davis AP, Özhatay N. Galanthus trojanus: a new species of Galanthus (Amaryllidaceae) from north-western Turkey. Bot J Linn Soc. 2001; 137: 409-412.

3. Davis AP. The genus Galanthus. In: A Botanical Magazine Monograph. Editor: Brian Mathew, Timber Press Inc., Oregon. 1999, pp. 165-170.

4. Davis AP. The genus Galanthus-snowdrops in the wild. In: Snowdrops a Monograph of Cultivated Galanthus. Editors: Matt Bishop, Aaron Davis, John Grimshaw, Griffin Press Publishing Ltd., Cheltenham. 2006, pp. 44-47.

5. Özhatay N. Diversity of bulbous monocots in Turkey with special reference. Chromosome numbers. Pure Appl Chem 2002; 74: 547-555.

6. Tarım ve Köy İşleri Bakanlığı, Doğal Çiçek Soğanlarının 2010 Yilı İhracat Listesi Hakkında Tebliğ (2009/55), Resmi Gazete, Sayı: 27404.

7. Proskurnina NF, Areshkina LY. On the alkaloids of Galanthus woronowii, J Gen Chem USSR 1947; 17: 12161219.

8. Proskurnina NF, Yakovleva AP. Alkaloids of Galanthus woronowii. V. Isolation of galanthamidine. J Gen Chem USSR 1956; 26: 179-180.

9. Yakovleva AP. The Alkaloids of Galanthus woronowii. VII. Isolation of tazettine. J Gen Chem USSR 1963; 33: 1647-1648.

10. Kintsurashvili L, Vachnadze V. Plants of the Amaryllidaceae family grown and introduced in Georgia: a source of galanthamine. Pharm Chem J-USSR 2007; 41: 492-494.

11. Szlàvik L, Gyuris À, Minàrovits J, Forgo $P$, Molnàr J, Hohmann J. Alkaloids from Leucojum vernum and antiretroviral activity of Amaryllidaceae alkaloids. Planta Med 2004; 70: 871-873.

12. Lamoral-Theys $D$, Andolfi, $A$, Goietsenoven, GV, Cimmino A, Le Calve B, Wauthoz N, Megalizzi V, Gras T, Bruyere C, Dubois J, Mathieu V, Kornienko A, Kiss R, Evidente, A. Lycorine, the Main Phenanthridine Amaryllidaceae Alkaloid, Exhibits Significant Antitumor Activity in Cancer Cells that Display Resistance to Proapoptotic Stimuli: An Investigation of StructureActivity Relationship and Mechanistic Insight. J Med Chem. 2009; 52: 6244-6256.

13. Şener B, Orhan İ, Satayavivad J. Antimalarial activity screening of some alkaloids and the plant extracts from Amaryllidaceae. Phytotherapy Res 2003; 17: 1220-1223.

14. Lopez S, Bastida J, Viladomat F, Codina C. Acetylcholinestrase inhibitory activity of some Amaryllidaceae alkaloids and Narcissus extracts. Life Sciences 2002; 71: 2521-2529.

15. Heinrich M, Galanthamine from Galanthus and other Amaryllidaceae-chemistry and biology based on traditional use. In: The Alkaloids Chemistry and Biology. Editor: Geoffrey Alan Cordell, Elsevier Inc., San Diego. 2010, vol. 68, pp. 157-165.

16. European Pharmacopoeia, Sixth Edition. 2007, pp. 12611266.

17. Rhee IK, Van de Meent $M$, Ingkaninan $K$, Verpoorte R. Screening for acetylcholinesterase inhibitors from Amaryllidaceae using silica gel thin-layer chromatography in combination with bioactivity staining. J Chromatogr A 2001; 915: 217-223.

18. Ünver-Somer $N$, Kaya G I, Sarıkaya B, Önür M A. Phytochemical studies on Galanthus woronowii Losinsk. 
17th Meeting on Plant Originated Crude Drugs, Kuşadası, Abstract Book, p. 87, 2007.

19. Kaya Gİ, Gözler T. Quantitative evaluation of the Specimens of Galanthus elwesii. J Fac Pharm Gazi 2003; 20: 71-78.

20. Fillik A. Some Pharmacognostical Studies on Galanthus gracilis Ćelak. Growing in Mount Nif, Kemalpaşa, İzmir. MSc Thesis, Institution of Health Sciences, Ege University, İzmir, 2002.

21. Kaya GI, Gözler B. Quantitative and cytotoxic activity determinations on Galanthus nivalis subsp. cilicicus. Fitoterapia 2005;76: 340-343.

22. Akbulut İ. Some Pharmacognostical Studies on Galanthus plicatus Bieb. subsp. byzantinus (Baker) D.A. Webb Growing Around Abant Lake, Bolu. MSc Thesis, Institution of Health Sciences, Ege University, İzmir, 2004.

23. Areshkina L. Ya. Alkaloids from snowdrop. Sovet Subtropiki. 1940; (11-12): 59. From: Khim Referat Zhur 1941; 4: 100 Chem. Abstr. (1943), 37: 64056.

24. Kovtun L, Patudin AV, Gorbunova GM, Gorbunov VD, Stikhin VA, Gogitidze SD, Nakaidze AK. Search for galanthamine in Galanthus L. and Leucojum L. Plants in Transcaucasia, Farmatsevtichnii Zhurnal (Kiev) 1978; 6:
59-62; Chem. Abstr. (1979), 90: 200291r.

25. Houghton PJ, Ren $Y$, Jayne-Howes M. Acetylcholinesterase inhibitors from plants and fungi. Nat Prod Rep 2006; 23: 181-199.

26. Berkov S, Bastida J, Nikoleva M, Viladomat F, Codina C. Rapid TLC/GC-MS identification of acetylcholinesterase inhibitors in alkaloid extracts. Phytochem Anal 2008; 19: 411-419.

27. Sarıkaya B, Kaya Gİ, Ünver-Somer N, Önür MA. Investigation of Galanthus woronowii with regard to acetylcholinesterase inhibitory activity. 18th Meeting on Plant Originated Crude Drugs, İstanbul, Fitomed Special Issue 2008; 6: 69.

28. Ünver Somer N, Sarıkaya B, Kaya Gİ, Önür MA, Bastida J. Isolation and structure elucidation studies on Galanthus woronowii Losinsk. 9th International Symposium on Pharmaceutical Sciences, Ankara, Proceeding and Abstract Book, p. 329, 2009. 